\title{
A Agência Informativa Católica Argentina (AICA) e a política na Argentina durante o "Processo de Reconstrução Nacional"
}

\author{
Jessie Jane Vieira de Sousa
}

\section{Apresentação}

O presente trabalho tem como objetivo analisar, com base no boletim informativo editado quinzenalmente pela Agência Informativa Católica Argentina (AICA), o aparente consenso construído pelo Episcopado argentino em torno do golpe militar ocorrido naquele país em 24 de março de 1976, chamado de El Proceso (Proceso de Reconstrución Nacional). A proposta é compreender a dinâmica das relações entre a Igreja Católica Argentina e os militares que tomaram o poder naquela ocasião na abordagem do noticiário publicado pela agência. Nesse momento nos interessam particularmente os boletins editados no final do ano de 1975 e início de 1976 e como, através dos mesmos, o Episcopado estudava aquela conjuntura política e as suas relações com as Forças Armadas.

Partimos da hipótese de que a AICA e seu boletim foram importantes na construção de uma aparente coesão no campo católico a respeito do que o Episcopado apontava como sendo "el camiño de los hombres y la busqueda de las verdaderas armas de la paz en la Argentina". E esse caminho foi o da "lucha antisubversiva" que "es una lucha en defensa de la moral, de la dignidad del hombre; es en definitivo una lucha en defensa de Dios". ${ }^{1}$ Entendemos que, naquela conjuntura marcada pela instabilidade política, o Episcopado argentino, através das suas homilias e do noticiário oriundo das suas pastorais, pregava a paz e ao mesmo tempo incentivava a presença dos militares como representantes legítimos da nacionalidade, chegando mesmo a admitir claramente que esse seria um desejo divino.

Segundo Emilio F. Mignone, o golpe militar ocorrido em 24 de março de 1976 havia sido anunciado com antecipação por alguns bispos. Em 23 de setembro de 1975, em uma homilia pronunciada perante o general Roberto Viola, então chefe do Estado Maior do Exército, o vigário castrense, monsenhor Victorio Bonamin, se perguntava se Cristo não queria que algum dia as Força Armadas fossem além das suas funções. ${ }^{2}$ No dia 29 de dezembro desse mesmo ano, monsenhor Adolfo Tortolo, presidente da Conferência Episcopal Argentina (CEA), durante um almoço da Câmara Argentina de Anunciantes, profetizou que se avizinhava "un proceso de purificación". ${ }^{3}$

Do ponto de vista metodológico faremos uma breve análise dos fatos prévios ao golpe militar para que possamos contextualizar o processo social e político no qual foram produzidas as condiçóes necessárias àquele desfecho. Daremos especial importância ao substrato ideológico comum aos atores em tela ao longo de todo o século XX. Interessa-nos articular duas dimensões do problema. Uma referida ao conjunto de questóes presentes no âmbito interno da Igreja desde os anos de 1950 e outra, a uma dimensão histórico-sociológica que tem como alvo a Igreja como fator de poder que, para mantê-lo, desenvolve uma série de estratégias visando ao mesmo tempo consolidar sua unidade interna e ampliar sua influência sobre a sociedade, sobretudo sobre as Forças Armadas.

Contudo, para evitar simplificaçôes ou interpretaçōes unilaterais, consideramos a Igreja Católica e as Forças Armadas como atores sóciopolíticos complexos, atravessados por conflitos e contradiçōes em seu interior. Ao longo da cobertura realizada pelo boletim no período estudado, podemos perceber, nas diferentes manifestaçóes dos bispos acerca da violência que marcava o cotidiano da vida política argentina, algumas dessas contradições no tocante às visões acerca do que o Episcopado entendia pela construção de um acordo de paz. Todavia, a partir do momento em que os militares assumem o poder, o discurso se modifica e o que predomina é um consenso de apoio ao regime. A partir do dia 24 de março, dia do golpe militar, o noticiário do boletim da AICA pode ser tomado como sendo representativo dessa posição do Episcopado e visava, sobretudo, criar uma unidade no pensamento católico sobre aquela conjuntura. 


\section{A fundação da AICA}

Em fevereiro de 1956 a Conferência Episcopal Argentina ${ }^{4}$ criava a sua agência informativa sob a direção de Don Miguel Woites, conhecido militante da Ação Católica Argentina. ${ }^{5}$ Desde então a Agência passou a publicar um Boletim bimensal com notícias selecionadas e encartes onde têm sido publicados, na íntegra, documentos episcopais, do Vaticano e notícias internacionais referentes ao mundo católico e, particularmente, ao trabalho paroquial no interior da Argentina.

Quando da sua criação o noticiário era construído a partir do serviço diário da Agência Informativa Católica (AICA), que, por sua vez, era dependente do Arcebispado de Buenos Aires e da Unión Acatólica Latinoamericana de la Prensa (UCLAP). Tratava-se, portanto, de uma iniciativa oficial da hierarquia católica e que deveria servir como centro irradiador do noticiário a ser transmitido ao mundo católico e à sociedade em geral. Ao longo dos anos, com a modernização dos meios de comunicação, a Agência passou a recolher informaçóes de outras Agências informativas e na atualidade continua sendo um importante instrumento na difusão das atividades do Episcopado argentino.

No momento do seu lançamento a iniciativa se relacionava com a experiência histórica imediata, aquela que se encerrara em outubro do ano anterior com a queda de Juan Domingo Perón, contra o qual a Igreja tanto havia se confrontado durante o ano de 1955 e que foi alcunhada por monsenhor Franscesch, o legendário editor da Revista Critério, como La Restauración. ${ }^{6}$ Era exatamente isso que o Episcopado objetivava com a nova Agência informativa que, segundo a Carta Pastoral lançada em outubro de 1955, seria fundamental para a construção da unidade dos católicos, algo que havia sido brutalmente atingido durante o último período peronista. ${ }^{7}$

A AICA e seu boletim tinham como missão a conformação de uma rede informativa em torno da qual os católicos e o clero, em particular, se uniriam na busca da cristianização daquela sociedade que, segundo os católicos, havia sido tão fortemente ofendida pelo suposto laicismo presente no peronismo. Em 2006, por ocasião dos festejos pelos cinquenta anos do lançamento da Agência, o atual arcebispo de Buenos Aires e presidente da Conferência Episcopal Argentina (CEA), cardeal Jorge Bergoglio, exaltou a importância daquela iniciativa ao enfatizar o "lugar en la Historia" que a AICA havia ocupado ao longo do processo de afirmação do catolicismo argentino e os desafios enfrentados ao longo do tempo.

$\mathrm{Na}$ realidade, a iniciativa que o Episcopado argentino havia tomado em 1956 era inovadora, uma vez que somente em 1963, por ocasião do Vaticano II, o papa iria afirmar que "todos los hijos de la Iglesia, de comum acuerdo, tienen que procurar que los medios de comunicación social, sin ninguna demora y con el máximo de enpeño, se utilicen eficazmente en las múltiplas obras del apostolado".

Essa emergência não significava que até então a Igreja Católica universal não havia se utilizado da imprensa, falada e escrita, ${ }^{8}$ para suas tarefas evangelizadoras, mas foi a partir da dácada de 1950 , com a instrumentalização das ciências sociais, ${ }^{9}$ que os processos modernizadores foram implementados no cotidiano do trabalho pastoral. No caso da Igreja na Argentina, tão fortemente conservadora, aquela iniciativa pioneira poderia causar espanto, mas os embates políticos enfrentados desde o início do século com os projetos liberais talvez lhe tenham dado consciência da necessidade de construir instrumentos pedagógicos que lhe possibilitassem constituir aquilo que tem sido chamado de mito da nação católica. ${ }^{10}$

A construção desse mito no início dos anos de 1930, propiciada pela derrota liberal, permitiu ao Episcopado argentino se aproximar do Estado apesar dos conflitos gerados no último período peronista. ${ }^{11}$ Em 1955 os católicos se uniam aos liberais, comunistas e socialistas para derrotar o que lhes era apresentado como o inimigo da nação católica, o peronismo. ${ }^{12}$ Todavia, o aparente consenso construído naquele momento se desfez com a explosão popular ocorrida logo após o golpe contra Perón e levou parte do clero e, particularmente os jovens, alguns ainda seminaristas, a questionar todas as referências políticas que haviam recebido dentro da estrutura da Igreja. Para muitos era particularmente assustador percorrer os bairros pobres das cidades onde, em contraste com a euforia das classes altas, a população chorava a queda daquele que identificava como sendo seu protetor. 
Foi, portanto, nessa conjuntura, quando se iniciava o desmoronamento da aparente coesão do mundo católico, que a AICA e seu boletim foram lançados. Como já dito, tratava-se de criar um instrumento informativo que pudesse disciplinar as hostes católicas e particularmente unir o clero em torno dos seus bispos. Fazia-se necessário uniformizar as informações que deveriam chegar ao mundo católico onde já iniciava o surgimento de novos conflitos potencializados pelo processo que levaria ao Concilio Vaticano II.

\section{A Igreja Católica na Argentina e o Concílio Vaticano II}

O processo de encontro da Igreja Católica universal com a democracia liberal estava em curso desde 1944, quando o papado, em sua radiomensagem natalina, anunciava que o integrismo deveria ser substituído como orientação central da Igreja. Com a derrota dos países do eixo era o momento da Igreja mudar suas alianças e, com o apoio dos Estados Unidos, começou, em vários países europeus, o processo de organização dos partidos democratas cristãos como instrumentos eficazes de combate ao comunismo. Esse foi o eixo em torno do qual o episcopado latino-americano passou a se organizar a partir da década de 1950 e nas décadas que se seguiram imediatamente à revolução cubana. Antes da sua morte, em outubro de 1958, o papa Pio XII já havia convocado a América Latina para formar um bloco católico que defendesse o continente do comunismo que, segundo ele, era o mal que estava assaltando o continente. ${ }^{13}$

Naquela conjuntura foi muito bem-vinda a ajuda da Igreja Católica norte-americana que, a partir de 1962, se articulou com a política da Aliança para o Progresso incentivando os partidos democratas cristãos do continente, particularmente no Chile, a implementar reformas no campo como forma de derrotar o comunismo. ${ }^{14}$ Em 1958, com a morte de Pio XII, assumiu o trono de Pedro o papa João XXIII, que, após três meses de papado, convocou o Concílio Vaticano II. No entanto, este só foi aberto em 1962.

Apesar do pouco entusiasmo com que o Episcopado argentino respondeu à convocatória conciliar, esse processo teve repercussóes inesperadas no meio católico daquele país, levando, inclusive, ao surgimento dos Sacerdotes para o Terceiro Mundo e ao comprometimento de um número expressivo de católicos e de padres e freiras nas lutas sociais que marcariam a Argentina nas décadas seguintes. ${ }^{15}$

As conclusões conciliares que supunham o abandono das concepções tomistas sobre as quais a Igreja na Argentina havia se estruturado desencadearam uma crise sem precedentes no campo católico tão marcado por essa tradição. O Episcopado argentino, tido como um dos mais tradicionalistas do continente, quase em sua maioria, havia sido formado no clima antiliberal da década de 1930 e continuava sendo animado pelo espírito de conquista que marcou aqueles tempos. Para eles a Igreja era um corpo perfeito e fazia-se necessário restaurar tudo em Cristo.

Somente alguns bispos recém-designados ${ }^{16}$ entendiam que se fazia necessária uma renovação pastoral através de uma nova abordagem nos estudos teológicos e, para tanto, promoveram organizaçôes que permitiam a participação de sacerdotes e laicos na vida interna das suas dioceses. ${ }^{17}$ Além de entenderem que era fundamental introduzir novas abordagens litúrgicas e pastorais como forma de sedimentar outras relaçôes da Igreja com a sociedade, as dioceses onde esses bispos viveram experiências inovadoras, não por acaso, eram dioceses recém-instaladas. ${ }^{18}$ Em alguns institutos e centros de estudos, foram introduzidas metodologias e abordagens teóricas oriundas das ciências sociais, propiciando o surgimento de diferentes possibilidades. ${ }^{19}$

No entanto, prevaleciam no poder da Igreja aqueles setores mais tradicionalistas, muitos ordenados em 1934, logo após o Congresso Eucarístico Internacional, e que permaneciam fiéis ao ideário da "nação católica". Tais bispos compartilhavam o poder com aqueles que entendiam que as mudanças deveriam ser graduais, de forma que pudessem ser realizadas sob a supervisão da hierarquia. Quase todos eram arcebispos e estavam à frente das dioceses mais importantes. Dos onze arcebispos que compunham a comissão permanente do Episcopado, em 1962, oito tinham mais de 65 anos. Foi em algumas dessas dioceses que se produziram os conflitos mais graves entre a autoridade episcopal com o clero e com os militantes laicos. 
Muitos analistas têm se debruçado sobre esses conflitos e, de maneira sintética, apresentaremos a seguir um painel sobre esses debates, baseado na obra de Martin Obregón. ${ }^{20}$ Segundo esse autor as primeiras análises sobre as relações da Igreja com o Estado e a sociedade tiveram como perspectiva analítica a chamada Teoria da Dependência; foram iniciadas logo após o Concílio Vaticano II e se mantiveram como referência até meados dos anos de 1960. Tais análises criticavam as estruturas tradicionais da Igreja, enfatizando a potencialidade das mudanças existentes no seu interior e, com isso, formulavam uma crítica à lógica que subordinava a mensagem evangélica e as necessidades dos fiéis aos interesses corporativos da instituição. ${ }^{21}$ Para esses analistas os temores da Igreja em relação à possibilidade de perder seus privilégios se manifestavam internamente a partir do princípio da autoridade e externamente com o apoio aos poderes estabelecidos. Para os autores que adotaram essa perspectiva, os conflitos desencadeados entre a hierarquia e setores dissidentes foram tomados como um "choque entre consciências e estruturas". Para outros analistas os conflitos surgidos no período pós-conciliar surgiram do contato entre diferentes setores católicos, particularmente aqueles que militavam em movimentos sociais, sobretudo no meio operário, e cujas posiçôes rapidamente se radicalizaram naquele período. Nesse cenário destaca-se o movimento Sacerdotes para o Terceiro Mundo e os principais estudiosos desse fenômeno são Gustavo Pontoriero e Pablo Martín. ${ }^{22}$

Para Lila Caimari ${ }^{23}$ "la fascinación de los analistas por esta nueva iglesia promotora del cambio social no tuvo sólo consecuencias benéficas para el progreso de los estudios sobre el tema" porque a supervalorização das potencialidades transformadoras atribuídas aos chamados setores progressistas dessa Igreja terminou obstruindo a realização de pesquisas sobre as alas tradicionais que, do ponto de vista institucional, foram determinantes para as posições que a Igreja desempenhou nos processos políticos que marcaram as décadas seguintes.

Nessa perspectiva, Jorge Soneira ${ }^{24}$ apresenta uma importante resenha sobre as diferentes estratégias construídas pela hierarquia católica desde o final do século XIX até 1976. Tais estratégias foram fundamentais para que a instituição mantivesse ou expandisse sua influência sobre determinados âmbitos da sociedade. Segundo esse autor, desde os anos de 1920 tais estratégias foram acompanhadas por um rígido controle sobre aqueles setores intermediários. Soneira assinala ainda a existência de fatores ideológicos ao apontar as principais correntes de pensamento que influenciaram as diferentes etapas da história da Igreja na Argentina.

Outro autor, Rubén Dri, ${ }^{25}$ realizou vários trabalhos que nos permitem apreender as relações da Igreja católica com os diferentes setores sociais. Para esse autor a dimensão ideológica fortemente antidemocrática dessa igreja é fundamental para que possamos compreender as coincidências programáticas existentes com os militares. Suas conclusões são similares às de Mignone ${ }^{26}$ para quem a hierarquia católica aderiu majoritariamente ao regime e, dessa forma, se furtou a defender os direitos humanos e isso foi possível pelo processo histórico marcado pela interdependência entre Igreja e Estado, que permitiu a criação de um substrato ideológico comum.

Para Arturo Fernández, ${ }^{27}$ em sua análise sobre as relações da Igreja com os sindicatos no período que vai de 1976 a 1987, a adesão do episcopado ao regime militar se deu graças às necessidades pertinentes à institucionalização religiosa, isto é, à necessidade de conseguir, através da repressão, disciplinar os setores dissidentes. Esta necessidade explicaria o processo de endireitizacão ocorrido com o Episcopado, através do qual os setores conservadores e moderados aceitaram a liderança dos integristas que compartilhavam o essencial dos postulados predominantes nas Forças Armadas. Nesta perspectiva Fernández matiza as diferentes posiçōes existentes dentro do episcopado diante do regime militar a partir de uma análise sociopolítica que aponta a existência de setores conservadores, ultraconservadores, modernistas e progressistas. Acrescenta ainda que na Argentina a Igreja conseguiu aumentar sua influência graças às suas relaçóes históricas com governos militares de diferentes matizes ao invés de prestigiar a formação de um partido social cristão. Afirma ainda que a Igreja vem mantendo em seu interior estruturas de poder que facilitam a ausência de governos democráticos e que esta prática reproduz o sistema de dominação intraelites. 
Para Loris Zanatta, ${ }^{28}$ que analisa as relações da Igreja com o peronismo, a formação de um bloco clérico-militar foi um dado destinado a transformar-se em referência fundamental para a compreensão da história política argentina. Para ele este bloco ideológico terminou por definir a nacionalidade a partir de um conjunto de elementos onde o catolicismo ocupava papel central.

Por fim, faz-se necessário citar o importante trabalho de Martín Obregón, para quem, após a análise dos documentos episcopais e das declarações públicas dos bispos argentinos, pode-se afirmar que a hierarquia católica manifestou uma adesão global ao regime militar que ocupou o poder em março de 1976. ${ }^{29}$ Para este autor as razões para tal adesão derivam de questões estruturais, entre as quais as afinidades ideológicas entre Igreja e Forças Armadas, construídas nas primeiras décadas do século XX, e que tiveram como pilar a identificação entre nação e catolicismo. Por outro lado, a existência de um conflito entre esta Igreja e a democracia é vista como ameaça às hierarquias naturais da sociedade e, como tal, propiciadora da penetração das ideologias de esquerda.

Estas questões se superpuseram ao clima de radicalização política, social e ideológica presente naqueles anos e à crise instaurada no interior da própria Igreja a partir dos anos de 1950 e radicalizada após o Concílio Vaticano II, a Conferência dos Bispos Latino-americanos realizada em Medellín, em 1968, ${ }^{30}$ e particularmente após a Conferência dos Bispos Argentinos, realizada em São Miguel, em 1969. Esse encontro dos bispos argentinos, em abril, tinha como objetivo atualizar a reflexão católica na Argentina a partir do encontro de Celam, ocorrido no ano anterior, e seus resultados foram entendidos como sendo influenciados pelo marxismo. Para os bispos argentinos o trabalho pastoral não deveria ser centrado nas questôes sociais. O documento final, onde os bispos argentinos se comprometiam com os fundamentos de Medellín, foi fruto de intensa controvérsia e muitos bispos a ele se opuseram. O documento teve como redatores assessores laicos ligados aos Sacerdotes para o Terceiro Mundo. Nesse momento a fissura dentro do Episcopado estava clara e o sentido de autoridade e obediência estava em questão.

Estas contradições se aprofundaram ao longo dos anos em que as lutas sociais foram se intensificando até chegar o momento em que Perón retorna à Argentina e morre. Era hora dos militares retomarem o poder para exterminar qualquer possibilidade de sobrevivência de todo e qualquer potencial opositor. Era hora da regeneração em Cristo!

\section{Narrativas legitimadoras}

A imprensa católica jogou um papel essencial no aprofundamento da crise e na legitimação da intervenção militar. Durante o primeiro semestre de 1975 as páginas dos boletins da AICA eram dedicadas às homilias e às declaraçôes de um conjunto de bispos que se referiam insistentemente à "crise moral" que, segundo eles, se apresentava sob diversas formas e que demonstrava um "oscurecimiento de los valores más nobles del espirito, que constituyen y configuran el alma misma de la pátria”. ${ }^{31}$

$\mathrm{Na}$ realidade, a "militarização" do integrismo católico se evidenciava desde 1975, quando os setores tradicionalistas do Episcopado ${ }^{32}$ - particularmente Tortolo e Bonamim, figuras centrais do Vicariato Castrense - desempenharam um papel fundamental nas relaçôes com os militares para a campanha favorável à intervenção das Forças Armadas. É sintomática a homilia pronunciada por monsenhor Bonamim, em 23 de setembro de 1975, na qual afirmava que "quando hay derramamiento de sangre hay redención", para logo assegurar que "Deus está redimiendo, mediante el Ejército, a la nación argentina". 33

Os últimos números do ano de 1975 repercutiam as mensagens dos bispos pronunciadas por ocasião das festas natalinas e relacionadas com a situação política que havia se agravado com o aumento da violência que se abatia sobre católicos e até mesmo sobre sacerdotes. Nesse sentido é interessante analisar a mensagem de monsenhor Vicente Faustino Zazpe, bispo de Santa Fé, um dos prelados que haviam apoiado as resoluçôes do Concílio e das conferências do Episcopado latino-americano. Em sua mensagem afirmava que a data era oportuna para que fossem analisados "acontecimientos nacionales" que "parecen aconsejar una reflexión de ciertos problemas - con minusculas - que podrian convertirse en problema - con maiuscula". ${ }^{34}$ 
A Agência Informativa Católica Argentina (AICA) e a política

na Argentina durante o "Processo de Reconstrução Nacional"

Jessie Jane Vieira de Sousa

Monsenhor Zazpe se referia "a las tensiones en el âmbito de lo político entre alguns miembros de la Iglesia, las Fuezas Armadas, la policia y el gobierno". Para ele,

en los últimos dias ha surgido una serie de situaciones conflictivas: en Formosa el señor bispo y sus sacerdotes han dejado sen la celebración de la Santa misa en señal de protesta; en Neuquén el conflicto ha tenido como vocero monseñor De Nevares y el general Buassi; en Córdoba, La Rioja e San Nicolas de los Arroyos fueron detenidos algunos sacerdotes; en varias partes del país ha producido un estado de alerta sobre parroquias y casas religiosas de concorrência juvenil. ${ }^{35}$

Segue denunciando, advertindo que

En nuestra diócesi de Santa Fé se ha proibido al capellán de la carcel de Coronda celebrar la Santa misa por los detenidos de presunción subversiva. Hasta el momento 'el sangre no há llegado ao rio', y esperamos que no lllegue pero sera prudente - como en medicina - prevenir antes que curar; sobre todo en el campo religioso tan resbaladizo, y onde lo imprevisible y lo imponderable pueden producir situaciones poco menos insolubles. ${ }^{36}$

Para monsenhor Zazpe,

El proceso político de la nación está empedrado de dificuldades que afectan a dimensiones vitales de la comunidad. Y algunas ya han rozado las instituiciones basilares del país. Las conocemos y es el momento de reiteralas denuncias que han formulado desde la oposición tanto frontal como moderada y aceptadas por el mismo oficialismo. Lo importante ahora es precaver la possibilidad de um nuevo detonante. ${ }^{37}$

Apesar de denunciar a atuação do aparato repressivo, o bispo termina por cobrar ainda mais repressão advertindo que

Las Fuerzas Armadas han tomado el problema de la seguridad en sus manos y han comenzado una acción incomprensiblemente demorada hasta el momento. Recién en febrero se ordenó al Ejército intervenir em Tucumán, pero hasta octubre no se habia reconocido, todavia de manera formal y sin limitaciones la participación de las Fuerzas Armadas en tal lucha antisubversiva. En la atualidad el problema ha desbordado las fronteras tucumanas y cubre parte del país. El salvajismo criminal de unos y la impunidad exasperante de otros constituyen nuestra historia cotidiana. El quadro parece escapar a los controles fundamentales y a cualquer coerencia explicativa o justificativa. ${ }^{38}$

Ao longo desse processo é interessante atentar para as mensagens de outros bispos que, como monsenhor Zazpe, haviam se comprometido com a renovação da Igreja na Argentina, como é o caso de monsenhor Angelelli para quem "la paz no es represión; no es fruto del miedo; no es fruto de componendas; no se realiza sin el hombre y sin justicia; sin encuentro. Se la construje; no es passividad ni conformismo" ${ }^{39}$

Contudo, nesse boletim de oito de janeiro de 1976, o bispo de Jujui, monsenhor José Miguel Medina, ao denunciar o que ele chamava de "errores e mentiras", aponta os culpados:

... son los que median en la injusticia y los que contentan con sola injusticia, y los ambiciosos insaciables, los que no amam y que la paz es fruto del amor y el ódio corrompe al pueblo. Son culpables los que están al margen del derecho, al margen del orden querido por Dios en Cristo. ${ }^{40}$

Explicita ainda que são culpados "los padres que no educan, los docentes que envenenan las mentes inexpertas, los cristianos no comprometidos, los eclesiales predicadores marxistoides... La situación es compleja, mui perniciosa y profundamente peligrosa". ${ }^{11} \mathrm{Na}$ opinião do bispo, "la solución, por lo tanto, no puede ser exclusivamente terrena, ni angelicamente celestial". A solução estava onde? A resposta aparece nesse mesmo boletim com o comunicado da Comissão Arquidioseana de "Justicia y Paz" de Mendoza que, ao denunciar a escalada de violência, afirmava que naquele momento era necessário "valorar el sacrifício de los agentes del orden publica" para "atajar el mal no bastan las mediendas represivas" porque "hay que buscar un acuerdo". 42

Ainda esse mesmo boletim publica integralmente a mensagem ${ }^{43}$ de monsenhor Antonio Quarracino, bispo de Avellaneda e mais tarde de La Plata, outro bispo que havia apoiado as resoluçóes do Vati- 
cano II, e o comunicado do Episcopado de Concepción exortando a necessidade de medidas urgentes. Não se referiam à violência da famosa Tríplice $\mathrm{A},{ }^{44}$ nome sob o qual agiam os grupos armados articulados pelas Forças Armadas, de segurança e pelo ministro do Bienestar Social, Lopez Rega. ${ }^{45}$ A violência a que os bispos se referiam era a dos grupos de extrema-esquerda que, segundo a historiografia recente, naquela conjuntura já estavam militarmente derrotados, e aos movimentos sociais que desde o início da década haviam se reorganizado para combater a ditadura de Juan Ongania ${ }^{46}$ e que, em 1973, com a volta de Perón, se sentiram fortalecidos particularmente nos enfrentamentos laborais.

Nessa mesma edição de oito de janeiro, o destaque é a peregrinação militar a Roma por ocasião do Ano Santo. Tal notícia valorizava o trabalho do Episcopado Castrense e, ao mesmo tempo, enfatizava o papel dos militares como guardióes da nacionalidade. Por ocasião da Jornada Mundial pela Paz, celebrada no dia primeiro de janeiro, o arcebispo de Córdoba, cardeal Francisco Primatesta, dirigindo-se à população através do rádio e da televisão, também clama por um acordo. Essa também é a mensagem de monsenhor Angelelli, ${ }^{47}$ bispo de La Rioja, que, como já dito, desde os anos de 1950 havia se comprometido com as lutas sociais.

O fato de ser publicada nesse momento a mensagem desse bispo pode indicar que ainda não havia um consenso sobre o que deveria ser um processo de negociação para se alcançar a paz. Mais tarde, o silêncio com que o Episcopado recebe a morte - por um presumido acidente automobilístico - desse bispo pode também ser tomado como um indicativo de que, a partir da deflagração do golpe, em março de 1976, não havia mais espaço para aqueles que não se alinhassem totalmente com os militares golpistas.

Nesta perspectiva, a mensagem de monsenhor Vicente Zazpe, bispo de Santa Fé e outrora considerado um bispo renovador, parece mais articulada com aquilo que será a orientação que prevalecerá ao longo do período que se avizinha. Para ele,

este ano de 1976, la jornada - aunque mundial - parece pensada para la Argentina. Nuestro quadro nacional es desolador y los puntos de referencia no ofrecen muchas alternativas de llegar a la paz. En esta ultima semana se han multiplicado los llamados a la ciudadania ante uno peligro imediato y quizas invitable. ${ }^{48}$

E vai além:

En la consciencia de la comunidad pátria... se há llegado a la certeza de que estamos frente a decisiones definitivas y que la paz pierde rapidamente el pequeno margen de posibilidad que hasta ahora habia retenido. Estas jornadas deben reter la resonancia de una clarinada para poner a la pátria a un único e definitivo dilema: paz profunda o destrucción profunda; paz estructurada o destrucción estructurada; paz imediata o destrucción imediata. La sentencia sanmartiniana recobra um inédito sentido: la Argentina será lo que debe ser en la paz o non será Argentina. ${ }^{49}$

Outro bispo também considerado renovador no período anterior, cardeal Raul Primatesta, cardeal de Córdoba, em conferência à imprensa repercutida no boletim, afirmava que o ano de 1976 não seria fácil, porque

Hay mucha muerte en la Argentina, lo que es una ofensa a Dios... Entonces Dios puede ordenar las rotas. Dios va a defender su criación. Va a defender el hombre, pero puede ser que el remédio sea duro también, porque la mano izquierda de Dios, dicen por alli, paternal, pero puede ser pesada. ${ }^{50}$

Este era o tom em torno do qual o Episcopado argentino analisava a conjuntura e profetizava o futuro. No ano anterior, o bispo de La Plata, monsenhor Antonio José Plaza, já havia formulado severas críticas ao governo constitucional de Isabelita onde, segundo ele,

no hay timón en la nave del Estado que, prudente y com firmeza, ponga remédio a esta situación. El gobierno ha marchado a la deriva, expuesto a la improvisación y a ejendez de sus dirigentes; la ausência de autoridade es el mal ejemplo dado desde arriba fomentando el desorden y el peculato. Pocas veces se ha visto un espetáculo tan impudico de corrupción en los poderes públicos; el delito comum, los raptos y los asasinatos son secuelas de la imoralidad institucionalizada. ${ }^{51}$ 
Monsenhor Plaza prossegue afirmando que "en este contexto de escândalo, desorden y violência, las Fuerzas Armadas han asumido la perigrosa y abnegada misión de combater la subversión y de dar una imagen de austeridad ante la falta de ella en los círculos civiles". Porém, "en esta patriótica tarea que incumbe a sua alta misión de defender la nacionalidad y la paz amenazadas por la cobarde, se contradice con la responsabilidad de los dirigentes politicos y se prejudica por la falencia del poder". Todavia, "las Fuerzas Armadas solamente pueden reprimir en el campo militar y de seguridad, pero no pueden en la supresión de las causas ecónomicos-sociales, politicas e morales de la violencia...". 52

No entanto, o bispo de La Plata também afirmava que

En la actualidad nacional, la Iglesia debe predicar toda claridad que la subversión terrorista es un crimen contra Dios y la Pátria, pero debe también condenar sin medias tintas el terrorismo impune, del cual se han denunciado conexiones paraoficiales. La Iglesia no se identifica con las instituiciones políticas y castrenses y por lo tanto no pueden se juzgadas con los parâmetros propíos de éstas. Cuando aplaude el acierto no lo hace desde la adhesión sectorial o política y cuando advierte o critica el erro no lo hace desde la oposición. Su voz debe ser siempre inédita y original; es decir desde el evangello. Anadamos una reflexión sobre el ministério de la caridad cono tercera raiz de tensiones y conflictos. ${ }^{53}$

E para matizar a posição ideológica a partir da qual a Igreja se posicionava diante das questôes nacionais dizia que

Seria el caso de Chile. Durante el gobierno de Salvador Allende el Episcopado en memorables documentos denunció las violaciones flagrantes del marxismo y en la actualidad ha entrado en conflicto con la junta militar por algunas extralimitaciones de ésta. La Iglesia no há variado su posición respecto del ateo y materialista, pero insiste también que la doctrina social católica promove y exige profundos cambios en el ordenamiento social y que por lo tanto no todos los cristianos con inquetudes de este tipo son marxistas disfrazados, idiotas útiles o enrolados enla subversión. ${ }^{54}$

Monsenhor Plaza referia-se à prisão de alguns padres e afirmava que

En orden a los presos políticos, la Comisión Ejecutiva del Episcopado por médio de su Presidente há solicitado a los cuatro ministérios sucesivos del interior que se aceleren los procesos que correspondan a la Justicia Federal y el Poder Ejecutivo, y no lo hecho por impulso una senda misericórdia de cumplicidad que exige dictamen acelerado de inocencia o culpabilidad, com absolvisión o condena. ${ }^{55}$

Referia-se à grave crise que envolvia parte do clero, inclusive com a prisão de alguns padres. Tais prisões já haviam sido denunciadas pelo bispo de Goya, Monsenhor Alberto Devoto:

Al escribirles esta carta, no puedo menos que ser consciente de los dificiles momentos que atraviesan hoy la iglesia local, al igual que otras del pais. Por diversos médios, ustedes se han enterado de la detención de los Padres Jorge Torres y Diego Orlandini, que fueran puestos em libertad al cabo de 11 dias. El procedimiento se hizo en base a denuncias e informaciones. ${ }^{56}$

É interessante salientar que tais denúncias cessaram após o golpe de março de 1976, quando as portas do Episcopado se fecharam para as famílias dos milhares de desaparecidos políticos sendo que entre eles se encontravam centenas de membros da Igreja, inclusive padres e bispos.

O chamamento à autoridade das Forças Armadas, presente na fala de Plaza, se explicita nas declarações de monsenhor Banamin para quem este "es um año para no olvidar" porque "La patria rescató en Tucuman su grandeza, mancillada en outros ambientes, renegada en muchos situales, y la grandeza se salvó en Tucuman por el Ejército Argentino". ${ }^{57}$

$\mathrm{Na}$ homilia, realizada na capela Stela Maris do Vicariato Castrense, em homenagem a um grupo de militares mortos, em 1974, em um suposto acidente aéreo, e com a presença do então comandante do Exército, Rafael Videla, e do chefe do Estado Maior, Roberto Viola, monsenhor Banamin vai ainda mais longe ao afirmar que 
Dios nos libre de olvidar el año de 1975... Estaba escrito, estaba en los planos de Dios que la Argentina no debia perder su grandeza, y la salvo su natural custodia: el Ejército. El argentino debe tener la vocación homérica de alimentarse con el túetano o la medula de león..." 58

Observa ainda que "que sea del soldadito, que sepa del general, y sepa del teniente, y de todos aquelles cujas gestas deben quedar en algún folheto o libro para ensenanza de este pueblo".

Referindo à ação do Exército em Tucuman, expressa que

la oración ha salido purificada de los cerros tucumanos, y la religión se ha impreso también en el hecho de que todo el país lentamente, advirtió que la lucha antisubersiva es una lucha en defensa de la moral, de la dignidad del hombre; es en definitivo, una lucha en defensa de Dios. Hasta el enemigo se encargo de hacerlo comprender reservando sus ataques más alevosos por deplelgar los en días de la crina del niño de Belén. ${ }^{59}$

Era evidente o clima de cruzada que havia se apoderado do Episcopado argentino. No dia seguinte ao golpe militar, monsenhor Tortolo lançava um chamamento à cooperação positiva no que ele entendia como sendo o começo de um processo de restauração do espírito nacional. No dia 30 de março, seis dias após a tomada do poder pelos militares, a hierarquia católica se fez presente no ato de posse do general Videla e, ao longo do mês de abril, a presença de bispos na sede do governo foi frequente.

Por ocasião da Páscoa, a maioria dos bispos manifestou seu apoio através de cartas pastorais e homilias que, em muitos casos, eram transmitidas para toda a população através de cadeias nacionais montadas pelas estações de rádio.

Nesse contexto, as palavras de monsenhor Aramburu, arcebispo de Buenos Aires, proferidas na catedral, adquirem importância especial porque enfatizavam que a história estava agora nas mãos do povo argentino e que não mais seria possível haver desentendimentos ou negar seu apoio. E declarava sua animada confiança a respeito do futuro do país e que tal esperança deveria ser compartilhada por todos. Fazia-se necessário, portanto, estar disposto a participar e a colaborar para alcançar o bem comum que a Argentina tanto necessitava. ${ }^{60}$

Esse era o tom das diferentes manifestações dos bispos. Para uns o entusiasmo se devia à presença dos militares no poder e, para outros, era a possibilidade de reconstrução da ordem e o redescobrimento do sentido do dever. A adesão se estendia à Santa Fé, especialmente pela "vocação cristã" do novo governo, e essa satisfação foi transmitida, no dia 21 de março, ao representante dos militares junto ao Vaticano. ${ }^{61}$

\section{Conclusão}

A Igreja Católica na Argentina tem sido acusada pelos organismos que naquele país lutam contra a impunidade, como um dos atores envolvidos, ainda que como força auxiliar, na violência implementada pelo Estado, e que teve como resultado milhares de assassinatos políticos. Diferente das igrejas católicas de outros países do Cone Sul, não se preocupou em construir outras narrativas sobre sua atuação naquele cenário político, onde tem sido alvo de tantas acusaçóes.

A pesquisa que ora apresentamos, na realidade, corrobora ainda mais para que tais acusações sejam ainda mais severas. Não se trata evidentemente de um julgamento moral, mas sim de uma tentativa de compreender como aquela Igreja pode se calar diante do assassinato de bispos, padres, e até mesmo de centenas de militantes católicos que faziam trabalhos pastorais. Muito tem sido escrito sobre os antecedentes históricos que levaram a este posicionamento, mas, ao buscar elementos empíricos presentes naqueles boletins semanais, argumentos teológicos em torno dos quais o Episcopado buscava legitimar seus alinhamentos políticos, evidencia-se o caráter autoritário com que a sociedade era pensada e a arrogância com que o sofrimento das pessoas era tomado. Sobretudo, o caráter disciplinador com que o processo era analisado e a permanente tentativa de construir um consenso em torno do apoio católico ao golpe militar.

De resto, em consonância com vários estudiosos sobre o tema, ao longo da pesquisa foi possível constatar que muitas das conclusões destes autores se confirmaram. A primeira constatação possível é 
de que ao longo do período o boletim buscou, em primeiro lugar, criar uma opinião de que o país vivia em absoluto caos por conta da ausência de autoridade e da evidente corrupção. Em segundo lugar, apresentar as Forças Armadas como a única instituição capaz de salvar a nação em consonância com os fundamentos morais apregoados pela Igreja e, em terceiro lugar, demonizar toda e qualquer oposição ao regime militar que se instaurou a partir de 24 de março e condenar qualquer gesto de oposição que pudesse surgir no mundo católico, seu alvo prioritário.

\section{Notas}

${ }^{1}$ AICA Ano XX no 994 de 08/01/76, p. 24.

${ }^{2}$ Mignone, Emilio. Iglesia y dictadura. 2ª ed. Buenos Aires: Colihue, 2006, (Ediciones del Pensamiento Nacional), p. 25.

${ }^{3}$ Verbitsky, Horacio. La última batalla de la tercera guerra mundial. Buenos Aires: Editorial Legasa, 1984, p. 15. Citado por Mignone, op. cit., p. 25.

${ }^{4} \mathrm{O}$ primeiro número foi publicado em junho de 1956.

${ }^{5}$ Com raras interrupções, Don Miguel Woites tem sido o diretor da AICA até os dias atuais. Nasceu em 1928 e foi militante da Juventude Operária Católica, tendo sido seu presidente em 1949. Em 1986 a Santa Sé o designou Cavalheiro Comendador de San Gregório Magno. Homenagens feitas pelo Episcopado argentino por ocasião dos 50 anos da Agência podem ser lidas no site www.aica.org.

${ }^{6}$ Revista Critério. Ano XXVIII, no 1.247, de 10 de outubro de 1955, p. 818.

7 Idem.

${ }^{8}$ São famosas as radiomensagens transmitidas pelos papas Pio XI e Pio XII.

${ }^{9}$ Carozzi, Maria Julia y César Cesarini Cernadas.(coord.) Ciências sociales y religión en América Latina. 1ª ed. Buenos Aires: Biblos, 2007.

${ }^{10}$ Zanatta, Loris. Del Estado liberal a la nación católica. Iglesia y ejército en los orígenes del peronismo, 1930-1943. I ed. Universidad Nacional de Quilmes, Buenos Aires, 1996.

${ }^{11}$ Bianchi, Susana. Catolicismo y liberalismo Religión y Política en la Argentina 1943-1955. Buenos Aires: Trama Editorial/ Prometeo, 2001. Caimari, Lilá. M. Perón y la Iglesia Católica. Religión, Estado y sociedad em la Argentina (1943-1955). Buenos Aires: Ariel Historia, 1994.

${ }^{12}$ Sobre as ideias e redes intelectuais no período ver Terán, Oscar. História de las ideas en la Argentina - Diez lecciones iniciales, 1980-1980. Buenos Aires: Siglo Veintiuno Editores, 2009, p. 227-280.

${ }^{13}$ Discurso a los rectores de los seminários mayores reunidos en Roma del 20 al 27 de septiembre de 1958. BEABA, año I, no 11, noviembre de 1958, p. 141. Citado por Verbitsky, Horacio. La violência evangélica. Buenos Aires: Editorial Sudamerica, 2008. Tomo II., p. 383.

${ }^{14}$ Kallas, Ana Lima. A paz social e a defesa da ordem: a Igreja Católica, o governo Allende e o golpe militar no Chile. Dissertação de Mestrado. Programa de Pós-graduação em História Social da UFRJ, 2008.

15 Touris, Claudia. “Religón y mundo obrero em la Argentina posperonista”. In: http:/religargrupo.blogspot.com/

${ }^{16}$ Como foi o caso de monsenhor Enrique Angelelli, filho de pequenos produtores italianos, foi ordenado em 1949 e completou sua formação em Roma onde conheceu José Leon Cardijin, fundador da Juventude Operária Católica. De regresso a Córdoba iniciou sua vida pastoral nos bairros pobres e nas favelas. Em 1952 foi o primeiro assessor da JOC. Em 1955 foi um destacado opositor ao peronismo, muito embora mais tarde tenha se aproximado destes setores por conta do seu trabalho pastoral, apesar das inúmeras crises que esse trabalho tenha provocado com a cúpula do Episcopado.

${ }_{17}$ Os bispos maiores de 65 anos, que em 1954 eram 35\% do corpo episcopal, em 1961 passaram a representar apenas 28\%.

${ }^{18}$ Entre 1957 a 1961 foram criadas 25 novas dioceses.

${ }^{19}$ Particularmente na Faculdade de Teologia da Universidade Católica, no Seminário de Villa Devoto, onde se destaca a figura do teólogo Lucio Gera, e na Revista Critério, naquele momento dirigida por Jorge Megia.

${ }^{20}$ Análise realizada a partir do trabalho de Obregón, Martin. Entre la cruz y la espada La Iglesia Católica Durante los primeros años del "Proceso". 1ํㅗㄹ ed. Bernal: Universidad Nacional de Quilmes, 2005.

${ }^{21}$ Entre outros podemos citar: Mayol, Alejandro; Arturo, Norberto y Armada. Los católicos posconciliares en la Argentina. Buenos Aires: Galerna, 1970; Gera, Lucio y Rodriges, Melgarejo. Apuntes para una interpretación de la Iglesia en Argentina. Montevideo: MIEC-JECI, 1970. 
22 Portoriero, Gustavao. Sacerdotes para o terceiro mundo: "el fermento en la masa”. Buenos Aires: CEAL, 1991; Martin, Pablo. Movimento de Sacerdotes para o Terceiro Mundo. Un debate argentino. Buenos Aires: Editorial Guadalupe/ Ediciones Castaneda, 1992.

${ }^{23}$ Caimari, Lilá. Perón y la Iglesia Católica. Buenos Aires: Ariel, 1994, p. 16.

${ }^{24}$ Soneira, Abelardo Jorge. Las estrategias institucionais de la Iglesia Católica, 1880-1976. 2 vol. Buenos Aires: CEAL, 1989.

${ }^{25}$ Dri, Rubén. Teologia y dominación. Buenos Aires: Roblando, 1987; Processo de la Iglesia argentina. Buenos Aires: Biblos, 1997.

${ }^{26}$ Op. cit.

${ }^{27}$ Fernández, Arturo. Sindicalismo e Iglesia. Buenos Aires: CEAL, 1990.

${ }^{28}$ Zanatta, Loris. Del Estado liberal a la nación católica. Buenos Aires: Editorial de la Universidad Nacional de Quilmes, 1996; do mesmo autor, Perón y el mito de la nación católica. Buenos Aires: Sudamericana, 1999.

${ }^{29}$ Op. cit.

${ }^{30}$ No momento em que os bispos latino-americanos se reuniam em Medellín, acontecia a VIII Conferência dos Exércitos Americanos sob o comando do general norte-americano William Westmoreland, que havia regressado do Vietnã. Nessa ocasião Agustín Lanusse propôs a constituição de um sistema interamericano de defesa dentro da OEA como forma de unir a luta com a subversão e como resposta à OLAS, ocorrida em Havana em 1966.

${ }^{31}$ AICA, 08/01/ 1976.

${ }^{32}$ Citado por Martin Obregón, op. cit., p. 50.

${ }^{33}$ Idem.

34 "La Iglesia y las Fuerzas Armadas". AICA 992, 24-12-1975, p. 12.

${ }^{35}$ Idem.

${ }^{36}$ Idem, ibid.

${ }^{37}$ Ibid.

${ }^{38}$ Ibid.

${ }^{39}$ Suplemento do Boletim. № 954 de 03-04-1975, p. 24.

${ }^{40}$ AICA, Ano XX, no 944.

${ }^{41}$ Idem.

${ }^{42}$ AICA, Ano XIX, no 944, p. 16.

${ }^{43}$ AICA, Ano XIX, no 941, p. 5-6; 9.

${ }^{44}$ Organização terrorista que tinha como objetivo assassinar militantes sindicais, estudantis, jornalistas, intelectuais e todos os militantes sociais argentinos e estrangeiros. A Tríplice A matou centenas de pessoas entre os anos de 1974 a 1976.

${ }^{45}$ Nudelman, Ricardo, op. cit., p. 23.

${ }^{46}$ Que pasa a nosotros los argentinos? Suplemento da AICA, N. 954, 3/4/1975, p. 10.

${ }^{47}$ Bispo que será assassinado pelos militares.

${ }^{48}$ AICA no 994, de 8/1/1976.

${ }^{49}$ Idem.

${ }^{50}$ AICA, Ano XIX, no 944, p. 19.

${ }^{51}$ AICA Suplemento do Boletim no 996-22-1-1976, p. 55.

${ }^{52}$ Idem.

${ }^{53}$ Idem.

${ }^{54}$ Idem, idem.

55 Ibid.

${ }^{56}$ Carta de Navidad. Doc. no 52 - Suplemento da AICA - 994 de 12/12/1975, p. 10-11.

${ }^{57}$ Idem, idem.

${ }^{58}$ Idem, ibid.

59 Ibid.

${ }^{60}$ AICA, 29/4/1976.

${ }^{61}$ Loris, Zanatta. "Chiesa e militari in Argentina. La Santa Sede di fronte al colpo de Stato del 24 marzo 1976. Interpretazione storica sulla base di alcuni documenti iniditi”, mimeo. 
A Agência Informativa Católica Argentina (AICA) e a política

na Argentina durante o "Processo de Reconstrução Nacional"

Jessie Jane Vieira de Sousa

\section{Referências bibliográficas}

BIANCHI, Susana. Catolicismo y liberalismo Religión y Politica en la Argentina (1943-1955). Buenos Aires: Trama Editorial / Prometeo, 2001.

CAIMARI, Lilá. M. Perón y la Iglesia Católica. Religión, Estado y sociedad en la Argentina (1943-1955). Buenos Aires: Ariel Historia, 1994.

CAROZZI, Maria Julia y César Cesarini Cernadas (Coord.) Ciencias sociales y religión en América Latina. 1aㅡ ed. Buenos Aires: Biblos, 2007.

DRI, Rubén. Teologia y dominación. Buenos Aires: Roblando, 1987.

. Proceso a la Iglesia argentina. Buenos Aires: Biblos, 1997.

FERNÁNDEZ, Arturo. Sindicalismo e Iglesia. Buenos Aires: CEAL, 1990.

GERA, Lucio y Rodriges, Melgarejo. Apuntes para una interpretación de la Iglesia en Argentina. Montevideo: MIEC-JECI, 1970.

KALLAS, Ana Lima. A paz social e a defesa da ordem: a Igreja Católica, o governo Allende e o golpe militar no Chile. Dissertação de Mestrado. Programa de Pós-graduação em História Social da UFRJ, 2008.

MARTIN, Pablo. Movimento de sacerdotes para o Terceiro Mundo. Um debate argentino. Buenos Aires: Editorial Guadalupe/ Ediciones Castañeda, 1992.

MAYOL, Alejandro; Arturo, Norberto y Armada. Los católicos posconciliares en la Argentina. Buenos Aires: Galerna, 1970.

MIGNONE, Emilio. Iglesia y dictadura. $2^{\mathrm{a}}$ ed. Buenos Aires: Colihue, 2006 (Ediciones del Pensamiento Nacional). OBREGÓN, Martin. Entre la cruz y la espada La Iglesia Católica durante los primeros años del "Proceso". 1ª ed. Bernal: Universidad Nacional de Quilmes, 2005.

PORTORIERO, Gustavo. Sacerdotes para el Tercer Mundo: "el fermento en la masa". Buenos Aires: CEAL, 1991.

SONEIRA, Abelardo Jorge. Las estrategias institucionais de la Iglesia Católica (1880-1976). 2 v. Buenos Aires: CEAL, 1989.

TERÁN, Oscar. Historia de las ideas en la Argentina. Diez lecciones iniciales, 1980-1980. Buenos Aires: Siglo Veintiuno Editores, 2009.

TOURIS, Claudia. "Religón y mundo obrero en la Argentina posperonista”. In: http:/religargrupo.blogspot.com/ VERBITSKY, Horacio. La violencia evangélica. Buenos Aires: Editorial Sudamerica, 2008. Tomo II.

ZANATTA, Loris. Del estado liberal a la nación católica. Iglesia y ejército en los orígenes del peronismo, 1930-1943. Buenos Aires: Universidad Nacional de Quilmes, 1996.

. La última batalla de la tercera guerra mundial. Buenos Aires: Editorial Legasa, 1984.

. Perón y el mito de la nación católica. Buenos Aires: Sudamericana, 1999.

. "Chiesa e militari in Argentina. La Santa Sede di fronte al colpo de Stato del 24 marzo 1976. Interpretazio-

ne storica sulla base di alcuni documenti iniditi”, mimeo.

\section{RESUMO}

O presente trabalho tem como objetivo analisar, através do noticiário publicado no boletim quinzenal da Agência Informativa Católica Argentina (AICA), o aparente consenso construido pelo episcopado argentino em torno do golpe militar ocorrido naquele país em 24 de março de 1976, chamado de El Proceso (Proceso de Reconstrucción Nacional). Nossa proposta é observar a dinâmica das relaçōes entre a Igreja Católica na Argentina e os militares que tomaram o poder naquela ocasiāo sob o enfoque do noticiário da agência. Nesse momento nos interessam particularmente os boletins editados no final do ano de 1975 e no início de 1976 e como, através dos mesmos, o Episcopado estudava aquela conjuntura politica e suas relaçôes com as Força Armadas.

Palavras-chave: cultura política, Igreja Católica, autoritarismo, poder, imprensa. 
A Agência Informativa Católica Argentina (AICA) e a política na Argentina durante o "Processo de Reconstrução Nacional"

Jessie Jane Vieira de Sousa

\begin{abstract}
ABSTRAT
The goal of this article is to analyze the so called consensus of the Argentinean Episcopate about the military coup which has happened in Argentina in March 24, 1976 and which was called El Proceso (Proceso de Reconstrución Nacional). For that goal I have used as primary sources the bimonthly newsletter published by the Argentinean Catholic Informative Agency (AICA), particularly the numbers edited between late 1975 and early 1976. I have researched this newsletter trying to understand how the dynamics between the Catholic Church and the military were built in the pages of that publication, especially on how the Episcopate analyzed that political juncture and its relations with the military. Keywords: political culture, Catholic Church, authoritarianism, power, press.
\end{abstract}

